DOI: $10.15193 /$ zntj/2019/121/311

HALINA MAKAŁA

\title{
ZASTOSOWANIE METODY WYSOKICH CIŚNIEŃ W PRZETWÓRSTWIE MIĘSA I PRODUKTÓW MIĘSNYCH
}

\author{
Streszczenie
}

Celem pracy była ocena możliwości i skuteczności stosowania metody wysokich ciśnień w przetwórstwie mięsa i produktów mięsnych oraz wskazanie kierunków rozwoju technologii HP (ang. high pressure) na podstawie przeglądu literatury przedmiotu.

Przedstawiono charakterystykę metody HP w utrwalania żywności, zasady oddziaływania wysokiego ciśnienia na produkty żywnościowe oraz zalety wynikające z jego stosowania. Przedłużenie trwałości produktów żywnościowych uzyskuje się m.in. przez redukcję liczby drobnoustrojów lub zmniejszenie aktywności enzymów. Podano mechanizm niszczenia mikroorganizmów przez wysokie ciśnienie. Scharakteryzowano potencjał metody HP w obszarze przetwórstwa mięsa i przetworów mięsnych. Omówiono wpływ wysokiego ciśnienia na zmiany w strukturze białek i na barwę mięsa, jak również na utlenianie tłuszczów w mięsie i jego przetworach. Przedstawiono możliwości zmniejszania zawartości soli w wyniku zastosowania wysokiego ciśnienia oraz jego wpływ na cechy jakościowe i sensoryczne produktów mięsnych. Opisano rolę stosowania wysokiego ciśnienia w surowcach i przetworach mięsnych w opakowaniach. Wymieniono propozycje zwiększania efektu letalnego w stosunku do mikroorganizmów poprzez łączenie metody HP z czynnikami wzmacniającymi synergistyczny efekt konserwowania mięsa i produktów mięsnych, takimi jak: niskie pH, dwutlenek węgla, środki przeciwdrobnoustrojowe, pakowanie próżniowe czy przechowywanie produktów w warunkach chłodniczych. Wskazano także kierunki rozwoju metody HP.

Słowa kluczowe: mięso i przetwory mięsne, metoda wysokich ciśnień (HP), skuteczność stosowania HP, trendy

\section{Wprowadzenie}

W ostatnich latach obserwuje się bardzo dynamiczny rozwój nowoczesnej techniki utrwalania żywności polegającej na poddawaniu produktów spożywczych o konsystencji płynnej lub stałej równomiernie w całej ich objętości działaniu ciśnienia od 100 do 1000 MPa w ciągu 5 - 20 min. Metoda wysokich ciśnień stosowana jest najczęściej

Dr inż. H. Makała, Instytut Biotechnologii Przemystu Rolno-Spożywczego im. W. Dąbrowskiego w Warszawie, ul. Rakowiecka 36,02-532 Warszawa. Kontakt: halina.makala@ibprs.pl 
w celu przedłużenia trwałości żywności, którą uzyskuje się poprzez redukcję liczby drobnoustrojów lub zmniejszenie aktywności enzymów [19, 22, 26, 31, 51, 56], przy równoczesnym zachowaniu właściwości, tj. barwy, smaku i składników odżywczych $[42,34]$. Metoda ta należy do niekonwencjonalnych sposobów utrwalania żywności. Jest ona alternatywą lub uzupełnieniem zabiegów konwencjonalnych, głównie termicznych.

Mechanizm niszczenia mikroorganizmów przez wysokie ciśnienie polega na tym, że zakłóca ono funkcje komórkowe organizmów żywych, wywołuje niekorzystne reakcje biochemiczne i powoduje nieodwracalne zmiany w błonie komórkowej oraz w błonie form przetrwalnikowych. Procesy te następują w przeciągu kilku do kilkunastu minut. Największą wrażliwość na wysokie ciśnienie wykazują komórki wegetatywne bakterii Gram-ujemnych. Obumierają one przy ciśnieniu powyżej $100 \mathrm{MPa}$. Bardziej wytrzymałe są komórki bakterii Gram-dodatnich, a zwłaszcza formy przetrwalnikowe. Przetrwalniki bakterii rodzajów Bacillus i Clostridium są w stanie wytrzymać ciśnienie rzędu $1200 \mathrm{MPa}$ [22, 27, 55, 63]. Technologia HP umożliwia skuteczną eliminację z mięsa i jego przetworów bakterii z rodzaju: Salmonella, Campylobacter jejuni, Listeria monocytogenes, a także Aeromonas hydrophila [48].

Wysokie ciśnienie może być alternatywnym sposobem dla cieplnego utrwalania przetworów mięsnych i niszczenia szkodliwych mikroorganizmów. HP może także wywierać istotny wpływ na kształtowanie profilu tekstury oraz cech sensorycznych wyrobu. Zaletą tej technologii jest brak oddziaływań zmniejszających zawartość składników odżywczych lub wywierających negatywny wpływ na właściwości produkowanych przetworów mięsnych [15]. Specyfika oddziaływania wysokiego ciśnienia znajduje również zastosowanie do modyfikowania cech funkcjonalnych zarówno składników surowca, jak i gotowego produktu, co pozwala na tworzenie pożądanych cech reologicznych [39, 40, 43, 48, 52].

Prowadzone są intensywne prace i badania nad rozszerzeniem możliwości wykorzystania techniki wysokociśnieniowej w przemyśle spożywczym, w tym przetwórstwie mięsa, zarówno jako nietermicznej metody utrwalania żywności, jak też jej przetwarzania, w tym tworzenia produktów o nowych cechach funkcjonalnych i sensorycznych.

Celem pracy była ocena możliwości i skuteczności stosowania technologii wysokich ciśnień w przetwórstwie mięsa i produktów mięsnych oraz wskazanie kierunków rozwoju metody HP na podstawie analizy danych literaturowych.

\section{Ogólna charakterystyka technologii wysokich ciśnień}

Niszczący wpływ podwyższonego ciśnienia na drobnoustroje i związaną z tym możliwość wykorzystania go do konserwowania żywności po raz pierwszy zaobserwowano pod koniec XIX wieku, kiedy zastosowano wysokie ciśnienie do utrwalenia 
mleka. Jako początek tej technologii przyjmuje się uruchomienie w Japonii w 1991 roku pierwszej półautomatycznej linii konserwowania soków cytrusowych, do których utrwalania zastosowano metodą wysokociśnieniową. Od tego czasu nastąpił dynamiczny rozwój techniki wysokociśnieniowej konserwowania różnych produktów żywnościowych, głównie w USA i w Japonii, a w Europie przede wszystkim w Hiszpanii i w Niemczech. Obecnie metodami wysokociśnieniowymi konserwowanych jest kilkaset różnych produktów żywnościowych, takich jak warzywa, owoce i ich przetwory, owoce morza, wędliny, mleko, produkty gotowe do spożycia i inne [22, 36, 47, 60].

Ideą wysokociśnieniowej metody konserwowania produktów spożywczych jest utrwalanie surowców bez potrzeby stosowania metod termicznych. Produkty finalne powinny charakteryzować się zmniejszoną bądź zdezaktywowaną florą mikrobiologiczną oraz zachowywać wartościowe składniki odżywcze, a jednocześnie nie tracić walorów sensorycznych [14, 58, 63].

Pod względem mechanicznym metoda ta podlega prawu Pascala. Ciśnienie wymusza zmiany objętości cieczy, którą jest woda bądź olej. Przyrost ciśnienia w jednym miejscu równy jest wzrostowi ciśnienia w innym punkcie systemu, sam system przeciwstawia się wymuszeniu z równą siłą. Woda poddana działaniu ciśnienia zmniejsza swą objętość o $4 \%$ przy ciśnieniu $100 \mathrm{MPa}$, podczas gdy przy $600 \mathrm{MPa}$ zmiana ta wynosi $15 \%$ (w temperaturze pokojowej). W czasie kompresji następuje wzrost temperatury i dochodzi to podgrzania medium i samej próbki. W procesach adiabatycznych wzrost temperatury wody jest rzędu 2 lub $3{ }^{\circ} \mathrm{C}$ na $100 \mathrm{MPa}$. Wzrost temperatury surowca lub produktu poddawanego działaniu ciśnienia zależy natomiast od jego właściwości termodynamicznych, takich jak pojemność cieplna czy współczynniki ściśliwości i rozszerzalności termicznej [29,63].

Do zalet metody wysokociśnieniowej zalicza się: zwiększenie trwałości produktów w wyniku niszczenia drobnoustrojów, równomierność działania ciśnienia w całej objętości, krótki czas trwania procesu oraz niewielkie zapotrzebowanie na energię. Stosuje się taką samą ilość energii bez względu na wielkość wsadu produkcyjnego [52, 63].

Wpływ wysokiego ciśnienia na produkty żywnościowe polega na:

- oddziaływaniu mechanicznym - zmniejszenie odległości międzyatomowych w nieznacznym stopniu wpływa na proste związki chemiczne,

- działaniach termodynamicznych i przemianach fazowych - zmiana stanu skupienia, w tym przemiany fazowe w wodzie i lipidach oraz fosfolipidach,

- oddziaływaniu na związki białkowe w tym na peptydy łańcuchowe,

- niszczącym działaniu na mikroorganizmy, takie jak drożdże, bakterie, zarodniki bakterii, przy czym najistotniejsze są przemiany fazowe prowadzące do uszkodzenia błon komórkowych mikroorganizmów [4, 27]. 
Zastosowanie wysokiego ciśnienia i innych czynników przeciwdrobnoustrojowych pozwala na zwiększenie efektu letalnego wobec mikroorganizmów, chociaż nawet w takich warunkach trudno jest osiągnąć całkowitą ich inaktywację w umiarkowanych temperaturach. Przy ustalaniu parametrów procesu ciśnieniowej inaktywacji należy mieć na uwadze, że mikroorganizmy są znacznie mniej wrażliwe na niekorzystne warunki, gdy znajdują się w środowisku żywności oraz że nawet pomiędzy szczepami w obrębie jednego gatunku występuje duże zróżnicowanie ich wrażliwości [38].

O zastosowaniu technologii wysokich ciśnień w przemyśle spożywczym krajów zachodnich zadecydowały przede wszystkim mechanizmy niszczące mikroorganizmy, jak i oddziałujące na związki białkowe. Ten sposób konserwowania określany jest również jako pasteryzacja ciśnieniowa czy paskalizacja - dla podkreślenia roli ciśnienia, co wynika z jego niszczącego działania na mikroorganizmy, podczas gdy mechanizmy powodujące oddziaływanie na związki białkowe umożliwiają ciśnieniową tenderyzację produktów $[17,35,40,43,46]$.

Potencjał technologii HP w przetwórstwie żywności spowodował jego komercjalizację w wielu regionach świata, w tym w Azji (Japonia, Chiny i Korea Południowa), Ameryce Północnej (Stany Zjednoczone, Kanada i Meksyk), Europie (Francja, Wielka Brytania, Niemcy, Hiszpania, Portugalia, Włochy i in.) i Australii. Szacuje się, że przetwarzanie żywności przy użyciu tej metody stanowi rynek o wartości ponad 2 miliardów USD [61].

\section{Wpływ HP na strukturę białek}

Struktura białek mięsa i przetworów mięsnych charakteryzuje się wysoką wrażliwością na ciśnienie makrocząsteczek w komórce. Ciśnienie naturalnie występujące w środowisku nie powoduje denaturacji białek, które dostosowują się do podwyższonego ciśnienia poprzez zmiany konformacji. Zmiany te są wystarczające do tego, by wpływać na ich funkcjonowanie, zmieniać właściwości białek lub powodować ich dezaktywację [4, 44, 53]. Zastosowanie metody HP do obróbki mięsa wpływa na stabilność mikrobiologiczną surowca. Kształtuje również właściwości funkcjonalne białek, takie jak: absorpcja i retencja wody czy zdolność emulgowania i solubilizacji biatek miofibrylarnych [26].

Niskie ciśnienia ( $<100 \mathrm{MPa}$ ) nie wpływają na wiązania kowalencyjne, a tym samym na strukturę pierwszorzędową. W przypadku wyższych ciśnień zerwaniu mogą ulegać wiązania wodorowe, co oddziałuje na struktury drugorzędowe białek [10]. Ciśnienia powyżej $150 \mathrm{MPa}$ mogą oddziaływać na struktury czwartorzędowe, a powyżej $200 \mathrm{MPa}$ powodują zmiany na poziomie struktur trzeciorzędowych. W przedziale ciśnień $100 \div 200 \mathrm{MPa}$ obserwuje się denaturację białek, agregację oraz przejście do fazy żelowej. Powyższe zmiany zależą od zawartości białek [4, 7]. 
Zastosowanie wysokiego ciśnienia zmienia właściwości białek mięśniowych Ulegają one zmianom fizykochemicznym, takim jak: denaturacja, dysocjacja, solubilizacja, agregacja i żelowanie, których szybkość i zakres uzależniony jest od poziomu ciśnienia, temperatury, pH i siły jonowej [28]. Najbardziej znaczący wpływ ciśnienia wykryto w mięsie w przypadku białek sarkoplazmatycznych i miofibrylarnych. Białka sarkoplazmy, głównie enzymy i pigmenty hemu, są bardzo podatne na denaturację pod wpływem ciśnieniu powyżej $200 \mathrm{MPa}$, podczas którego zmienia się zdolność zatrzymywania wody i barwa mięsa [37]. Białka miofibrylarne są powiązane ze strukturą mięsa i rozkładają się, gdy ciśnienie wynosi $300 \mathrm{MPa}$ i więcej. W wyniku tego następuje denaturacja, aglomeracja i tworzenie żelu [9, 18, 19, 59].

W procesie tenderyzacji „ciśnieniowej” zachodzą istotne zmiany wodochłonności (WHC, ang. water-holding capacity) tkanki mięśniowej. W efekcie działania wysokiego ciśnienia następuje rozluźnienie struktur wewnątrz- i międzykomórkowych, powstanie nowych przestrzeni dostępnych dla wody, a tym samym zwiększenie istniejących. To powoduje wzrost wodochłonnoścu mięsa, co ma istotne znaczenie w jego procesie przetwórstwa [12, 13, 33].

\section{Wpływ HP na barwę mięsa}

Przy zakupie mięsa i przetworów jednym z najważniejszych wyróżników jakości dla konsumenta jest ich wygląd zewnętrzny i barwa. Barwa mięsa zależy od ilości i stanu chemicznego obecnych hemoprotein, a także od struktury mięsa [10,54].

Badania wskazują, że HP wywołuje drastyczne zmiany barwy mięsa świeżego, podczas gdy w peklowanych produktach mięsnych obserwowane zmiany są dopuszczalne i zależą od poziomu zawartości i aktywności wody $\left(\mathrm{a}_{\mathrm{w}}\right)$. Są one spowodowane utlenianiem mioglobiny $\mathrm{j}$ do metmioglobiny $[2,16]$.

Inaktywację drobnoustrojów w mięsie zwykle osiąga się przy ciśnieniu powyżej $400 \mathrm{MPa}$. W efekcie takiego wzrostu ciśnienia występuje przebarwienie mięsa z powodu denaturacji białka [64]. Już zastosowanie ciśnienia powyżej 200 MPa powoduje w ciągu kilku minut w niskich temperaturach drastyczną zmianę barwy czerwonego mięsa [5, 62]. W większości przeprowadzonych badań [16, 27, 28, 54, 62] stwierdzono wzrost składowej jasności barwy mięsa $\left(\mathrm{L}^{*}\right)$ w zakresie stosowanego ciśnienia $200 \div$ $350 \mathrm{MPa}$ i zmianę czerwonej barwy na jaśniejszą, różową. Wartość składowej czerwonej barwy $\left(\mathrm{a}^{*}\right)$ zmniejszała się przy ciśnieniu $400 \div 500 \mathrm{MPa}$, powodując zmianę barwy mięsa na szarobrązową o wyglądzie podobnym do produktu gotowanego, jednak był to parametr bardziej zmienny i zależny od typu eksperymentu (tj. rodzaju mięsa, stanu rozdrobnienia oraz warunków technologii HP). Pod wpływem wysokiego ciśnienia wartość barwy żółtej (b*) wzrastała lub pozostawała na tym samym poziomie. Wykazano również, że zmiany barwy mięsa wieprzowego poddanego obróbce pod ciśnieniem $200 \div 800 \mathrm{MPa}$, w temp. 5 i $20^{\circ} \mathrm{C}$ przez 10 min zależą głównie od wysokości 
ciśnienia, w mniejszym stopniu - od zastosowanej temperatury [3]. Wielkość i natężenie niekorzystnych zmian barwy pod wpływem HP są zależne od zawartości mioglobiny i dotyczą w większym stopniu świeżego mięsa czerwonego, np. wołowego niż mięsa wieprzowego, drobiowego czy wędlin. Pod wpływem wysokiego ciśnienia mięso staje się jaśniejsze, może przyjmować konsystencję żelu, przez co traci typowy wygląd świeżego surowca $[39,52]$.

Hać-Szymańczuk i wsp. [21] wykazali, że zastosowanie wysokociśnieniowego procesu produkcji polędwicy sopockiej i surowej polędwicy wędzonej wpłynęło na rozjaśnienie barwy produktów oraz niekorzystne zwiększenie ilości wycieku. Stwierdzili również, że niepożądane zmiany można ograniczać poprzez zmianę parametrów procesu, tj. usuwanie tlenu i podnoszenie wartości $\mathrm{pH}$ produktów, co z kolei można osiągnąć przez zastosowanie odpowiednich czynników dodatkowych.

\section{Wpływ HP na utlenianie tluszczów w mięsie}

Tłuszcze biorą udział w kształtowaniu cech smakowo-zapachowych mięsa i przetworów mięsnych [13]. Podczas obróbki termicznej mięsa zachodzą łagodne reakcje oksydacji i degradacji lipidów, w wyniku których powstają pożądane związki smakowo-zapachowe. Długotrwałe przechowywanie mięsa powoduje natomiast znaczne zmiany oksydacyjne we frakcji lipidowej i przyczynia się do tworzenia posmaku jełkiego, z odczuciem smaku gorzkiego, kwaśnego lub alkalicznego [57].

Produktami utleniania tłuszczów odpowiedzialnych za powstawanie zjełczałego, niepożądanego smaku i zapachu są: niskocząsteczkowe substancje lotne, głównie krótkołańcuchowe aldehydy oraz powstające z nich wskutek utleniania kwasy. Najbardziej podatne na utlenianie są wielonienasycone kwasy tłuszczowe, wchodzące głównie w skład fosfolipidów membran komórkowych [23, 49].

Ciśnienie rzędu $300 \div 600 \mathrm{MPa}$ ma kluczowe znaczenie dla zainicjowania utleniania lipidów w świeżej wieprzowinie, mięsie wołowym i drobiowym, a także w produktach mięsnych, co może prowadzić do znaczących zmian zawartości lipidów, fosfolipidów i składu kwasów tłuszczowych, w tym wolnych kwasów tłuszczowych [24, 29, 30, 37]. Mechanizmy utleniania lipidów wzbudzane przez HP nie są w pełni poznane. Przypuszcza się, że HP może przyspieszać utlenianie lipidów w wyniku zwiększenia dostępności żelaza $\mathrm{z}$ hemoprotein i przerwania membran międzykomórkowych [2].

Utlenianie jest jednym z najważniejszych czynników niedrobnoustrojowej degradacji mięsa [20]. Utlenianie lipidów zwykle nie jest widoczne bezpośrednio po obróbce metodą HP, ale może nastąpić podczas przechowywania surowca w stanie schłodzonym. Utlenianie wpływa negatywnie na jakość mięsa poprzez pogorszenie jego smaku i zapachu (jełczenie), zmiany barwy, utratę wartości odżywczej oraz zmiany właściwości teksturalnych i funkcjonalnych powiązanych $\mathrm{z}$ denaturacją białka [5]. W celu hamowania utleniania lipidów w mięsie i przetworach mięsnych proponuje się ograni- 
czanie dostępności tlenu w opakowaniu, stosowanie aktywnych opakowań antyoksydacyjnych lub stosowanie przeciwutleniaczy pochodzących z naturalnych produktów ubocznych (ziół) i/lub ich kombinacji [1, 54].

\section{Możliwości zmniejszania zawartości soli}

Mięso i przetwory mięsne są na drugim miejscu (po wyrobach piekarniczych) wśród produktów uznawanych za główne źródło sodu w codziennej diecie. Zarówno konsumenci, jak i producenci dążą do jego ograniczenia ze względów zdrowotnych. Proces wysokociśnieniowy okazał się metodą, która może wpłynąć na poprawę słonego smaku w szynkach surowych dojrzewających, poddanych działaniu ciśnienia 300, 600 i $900 \mathrm{MPa} / 300 \mathrm{~s}$. Wykazano, że przetwarzanie wysokociśnieniowe ma doskonały potencjał jako uzupełniająca technologia zmniejszająca zawartość soli i wydłużająca okres przydatności produktu do spożycia [45].

Grossi i wsp. [18] dokonali oceny interakcji między wysokim ciśnieniem a stężeniem soli w produktach mięsnych. Autorzy zastosowali ciśnienie hydrostatyczne na poziomie 400, 600 i $800 \mathrm{MPa}$ w procesie produkcji kiełbas wieprzowych, które różnicowała zawartość soli (1,2 i 1,8 \%) oraz dodatek takich składników, jak marchew i włókna skrobi ziemniaczanej. Autorzy dowiedli pozytywnego wpływu wysokiego ciśnienia w produkcji przetworów mięsnych o obniżonej zawartości soli [18]. W innych badaniach próbki kiełbas wieprzowych o zawartości soli [\%]: 0,5, 1,0, 1,5, 2,0 i 2,5 poddano działaniu ciśnienia $150 \mathrm{MPa} / 5 \mathrm{~min}$. Stwierdzono, że w kiełbasach o zawartości soli poniżej 1,5\% ciśnienie miało negatywny wpływ na barwę, teksturę, soczystość i jędrność produktów, natomiast obróbka produktów o zawartości soli powyżej $2 \%$ umożliwiła uzyskanie kiełbas bez oznak negatywnego wpływu ciśnienia na ich cechy sensoryczne [42].

Badania przeprowadzone przez Rodriguesa i wsp. $[50,51]$ obejmowały wysokociśnieniowe przetwarzanie wieprzowiny $\left(350 \mathrm{MPa} / 6 \mathrm{~min} / 20^{\circ} \mathrm{C}\right) \mathrm{z}$ dodatkiem soli $(1,5$ $\div 3,0 \%)$ i fosforanu $(0,25 \div 0,5 \%)$. Stwierdzono, że pod wpływem HP nastąpił synergiczny efekt między teksturą a zdolnością zatrzymywania wody, co wskazuje na możliwość rozwoju przetwórstwa produktów mięsnych o małej zawartości sodu i bez dodatku polifosforanów. Oceniano również wpływ HP (200 i $\left.300 \mathrm{MPa} / 5 \mathrm{~min} / 5^{\circ} \mathrm{C}\right)$ na stężenie tripolifosforanu sodu i chlorku sodu w produkcji hamburgerów. Receptura hamburgerów uwzględniała składniki: $80 \%$ chudego mięsa $(\mathrm{m} / \mathrm{m}), 10 \%$ wody $(\mathrm{m} / \mathrm{m})$, 0,1 lub $2 \%$ chlorku sodu i/lub $0,0,25$ lub $0,5 \%$ tripolifosforanu sodu. Wykazano, że zaobserwowane zmiany tekstury i właściwości technologiczne produktów mięsnych o obniżonej zawartości soli były związane z rodzajem soli, poziomem stężenia i zastosowanego ciśnienia $(200 \div 300 \mathrm{MPa})[50,51]$.

Badano wpływ wysokiego ciśnienia na komercyjne, peklowane produkty mięsne. Wykazano, że w badanym schabie i szynce dojrzewającej poziom odczuwanego zaso- 
lenia zwiększył się po zastosowaniu wysokiego ciśnienia > $500 \mathrm{MPa}$. Nie zaobserwowano jednak wzrostu zawartości soli po zwiększeniu ciśnienia, stąd wzrost percepcji smaku słonego nie może być związany ze zwiększoną zawartością soli. W związku z tym zasugerowano, że wysokie ciśnienie zmieniło interakcje między jonami sodu i białkami, na skutek czego uwolnione zostały jony $\mathrm{Na}^{+}$i stały się bardziej dostępne dla kubków smakowych. To dowodzi możliwości zastosowania wysokiego ciśnienia do zmniejszania zawartości soli w produkcie, przy wzroście odczuwanego zasolenia. HP jest techniką o dużych możliwościach jej praktycznego zastosowania [50, 51, 54].

$\mathrm{Z}$ dotychczas przeprowadzonych badań wynika, że na rozwój niskosodowych produktów mięsnych może wpływać wiele czynników, w tym interakcje między parametrami metody HP (ciśnieniem, temperaturą i czasem), zawartość soli i stężenie substancji dodatkowych (polifosforanów), które decydują o właściwościach funkcjonalnych produktów mięsnych [39, 54].

\section{Wpływ HP na cechy jakościowe i sensoryczne mięsa i jego przetworów}

Wykorzystanie wysokiego ciśnienia hydrostatycznego w przemyśle mięsnym może mieć praktyczne zastosowanie do poprawy jakości surowca i przetworów.

HP wpływa na parametry jakościowe świeżego mięsa, szczególnie na jego konsystencję oraz barwę, które mogą być modyfikowane [2]. W wyniku działania wysokiego ciśnienia, w zależności od jego poziomu, następuje degradacja lub modyfikacja białek mięsnych, dezaktywacja enzymów, zachodzą zmiany w interakcji substrat - enzym oraz $\mathrm{w}$ węglowodanach i tłuszczach $[6,26]$. Wartość odżywcza, zawartość witamin i większość substancji odpowiedzialnych za smak produktów pozostają jednak bez zmian. W przeciwieństwie do obróbki cieplnej, która oddziałuje zarówno na wiązania kowalencyjne, jak i niekowalencyjne, obróbka wysokociśnieniowa prowadzona w temperaturze pokojowej i umiarkowanej rozrywa jedynie stosunkowo słabe wiązania chemiczne (wiązania wodorowe, hydrofobowe, jonowe). Związki o małych cząsteczkach, takie jak: witaminy, aminokwasy, cukry proste i związki smakowo-zapachowe nie ulegają zmianom [11].

Oprócz zdolności do konserwowania żywności, technologia wysokich ciśnień ma również wpływ na kształtowanie tekstury żywności i została wskazana jako proces fizyczny mający zastosowanie do zmiękczania (skruszania) mięsa i produktów mięsnych bez stosowania substancji dodatkowych. Takie modyfikacje strukturalne białek mięsnych są również wykorzystywane przez przemysł spożywczy w opracowywaniu nowych produktów $[5,54,55,59]$.

Hać-Szymańczuk i wsp. [22] badali cechy jakościowe i trwałość polędwicy sopockiej oraz surowej polędwicy wędzonej poddanych działaniu ciśnienia o wielkości $600 \mathrm{MPa}$ w ciągu $30 \mathrm{~min}$, w temperaturze pokojowej, a następnie przechowywanych przez 6 i 8 tygodni w warunkach chłodniczych. Autorzy wykazali, że zastosowanie HP 
skutkowało wydłużeniem trwałości polędwicy sopockiej do 6 tygodni przechowywania. Nie stwierdzono pogorszenia smaku, zapachu i konsystencji wyrobu, a w przechowywanej surowej polędwicy wędzonej nie rozwijały się drobnoustroje mezofilne, psychrofilne i kwaszące.

Pietrzak [47] oraz Pietrzak i wsp. [48] oceniali wpływ HP w produkcji żywności wygodnej z mięsa drobiowego na bezpieczeństwo i wyróżniki jakościowe produktu. Analizowano właściwości oraz trwałość kotlecików z mięsa drobiowego poddanych obróbce ciśnieniem o wielkości $500 \mathrm{MPa}$, w ciągu $10 \mathrm{~min}$ i w temp. $10^{\circ} \mathrm{C}$. Wykazano, że zastosowane ciśnienie nie decydowało o ilości wycieku podczas przechowywania kotlecików i nie miało wpływu na ich teksturę, barwę oraz szybkość utleniania lipidów. Pozytywnym skutkiem oddziaływania wysokiego ciśnienia była znaczna redukcja drobnoustrojów mezofilnych, psychrotrofowych oraz bakterii kwasu mlekowego w zapakowanych próżniowo kotlecikach podczas ich 3-tygodniowego przechowywania w temp. $4-6^{\circ} \mathrm{C}$, co potwierdziło założenie, że metoda wysokich ciśnień może być skutecznym sposobem przedłużenia trwałości tego typu wyrobów.

W handlowych produktach mięsnych surowo dojrzewających mikroorganizmy występują głównie na powierzchni. Mogą one wniknąć do produktu z powierzchni batonu lub plastra podczas krojenia lub pakowania. Ponadto procesy takie, jak trybowanie, cięcie czy krojenie wiążą się z ryzykiem zanieczyszczenia patogenami. Campus [7] badał właściwości sensoryczne i mikrobiologiczne szynki surowo dojrzewającej poddanej działaniu ciśnienia o wielkości $600 \mathrm{MPa}$ w ciągu 9 min. Obróbka wysokociśnieniowa pozwoliła na ograniczenie Listeria monocytogenes do nieznacznego poziomu. Proces spowodował również niewielkie obniżenie wartości parametru składowej barwy a* (czerwonej) i poprawę percepcji smaku słonego. Zmiany były odwrotnie proporcjonalne do czasu dojrzewania szynki [7].

Cegiełka i wsp. [8] prowadzili badania nad możliwością zastąpienia surowca wieprzowo-wołowego w kiełbasach homogenizowanych przez mięso drobiowe oddzielone mechanicznie (MDOM) w procesie wysoko- i niskociśnieniowym. Wykazano, że zastosowanie MDOM odseparowanego obiema technikami nie spowodowało obniżenia jakości sensorycznej kiełbas w odniesieniu do wyrobu zawierającego w składzie mięso wieprzowe i wołowe.

Oprócz zastosowania techniki wysokich ciśnień w przetwórstwie produktów żywnościowych dla ludzi, producenci używają HP do produkcji naturalnej żywności dla zwierząt domowych. Metoda ta może być również stosowana w przemyśle farmaceutycznym i kosmetycznym [65].

\section{Rola HP w surowcach i przetworach mięsnych w opakowaniu}

Ważnym elementem współczesnej dystrybucji mięsa jest wykorzystanie techniki pakowania próżniowego. W czasie przechowywania opakowane próżniowo lub w at- 
mosferze gazów surowce i przetwory mięsne są chronione przed niepożądanymi efektami, takimi jak: przebarwienia, nieprzyjemny zapach i posmak, utrata substancji odżywczych, zmiany tekstury [66].

Wysokie ciśnienie jako metoda konserwowania może mieć zastosowanie zarówno do surowców, jak i przetworów mięsnych zapakowanych próżniowo, które mogą być wtórnie zanieczyszczone podczas porcjowania lub pakowania [48]. Jeśli mięso zostanie poddane działaniu HP po zapakowaniu, możliwe jest zmniejszenie wtórnego zanieczyszczenia, utrzymanie jego świeżości i wydłużenie okresu przydatności do spożycia [25]. Metoda HP jest skuteczna i bezpieczna przede wszystkim w przypadku konserwowania przetworów mięsnych w opakowaniach $\mathrm{z}$ folii wielowarstwowej. Celem jest zapewnienie bezpieczeństwa produktów długo przechowywanych (RTE - Ready to Eat) zwłaszcza wtedy, gdy obróbka cieplna jest niemożliwa lub niewygodna. Warunki pasteryzacji mięsa i produktów mięsnych techniką HP to: ciśnienie w granicach $400 \div$ $600 \mathrm{MPa}$, czas $-3 \div 7 \mathrm{~min}$, temperatura pokojowa. Mięso, przetwory i gotowe dania mięsne, takie jak: hamburgery (USA), carpaccio (Holandia), tatar (Holandia), przekąski mięsno-serowe (Grecja), pieczone kurczęta (USA), które wcześniej poddano działaniu ciśnienia, zostały wprowadzone na rynek przez wiele firm na świecie [53].

\section{Lączone technologie konserwowania}

Zastosowanie wysokiego ciśnienia i innych czynników przeciwdrobnoustrojowych pozwala na zwiększenie efektu letalnego wobec mikroorganizmów, chociaż nawet w takich warunkach trudno jest osiągnąć całkowitą ich inaktywację w umiarkowanych temperaturach. Optymalnym rozwiązaniem wydaje się łączenie dwóch lub więcej metod konserwowania, w wyniku czego zwiększa się stabilność mikrobiologiczna, jakość sensoryczna i właściwości odżywcze produktów żywnościowych [38, 66].

Połączenie innych technik/technologii z metodą HP zwiększa działanie przeciwdrobnoustrojowe procesów niskociśnieniowych i minimalizuje niepożądane zmiany wywołane ultrawysokimi ciśnieniami (powyżej $400 \mathrm{MPa}$ ) [2]. W przypadku skutecznego zastosowania tej metody można zaobserwować efekt synergistyczny, gdy oba czynniki konserwujące łącznie wzmacniają działanie każdego czynnika z osobna. W przypadku mięsa i produktów mięsnych opisano synergistyczne efekty metody HP z udziałem czynników przeciwdrobnoustrojowych: niskiego $\mathrm{pH}$, dwutlenku węgla, pakowania próżniowego i przechowywania w warunkach chłodniczych $[28,36]$.

\section{Kierunki rozwoju metody HP}

Producenci żywności wykorzystują zalety technologii HP, aby zdobywać nowe rynki, tworzyć nowe produkty czy wydłużyć trwałość istniejących już wyrobów. Pomimo tego, że wpływ i zastosowanie wysokiego ciśnienia na trwałość i właściwości zarówno przetworów mięsnych, jak i gotowych do spożycia produktów jest dość do- 
brze poznany, to nadal podejmowane są prace badawcze nad wdrożeniem tej techniki do nowych procesów przetwórczych [48]. Szerokie zastosowanie utrwalania metodą HP szynek surowo dojrzewających lub parzonych, kiełbas i dań gotowych do spożycia ma miejsce w USA oraz wielu krajach europejskich. Przykładowo producent krojonego w plastry mięsa i sałatek poprzez użycie HP zwiększył bezpieczeństwo swoich produktów wydłużając ich trwałość. Dzięki temu może dostarczać konsumentom bezpieczne produkty, gdyż zachowanie łańcucha chłodniczego nie zawsze jest prawidłowe [65].

Żywność utrwalana metodą wysokich ciśnień jest określana jako "nowa żywność". Jest ona w znacznym stopniu równoważna tradycyjnej żywności obecnej na rynku, można ją traktować na poziomie regulacji krajowej bez konieczności stosowania się do nowej regulacji dotyczącej żywności. Zastosowanie HP do produktów mięsnych odnosi się głównie do wyrobów gotowych do spożycia, gotowanych i dojrzewających. Badania dotyczące zastosowań przemysłowych w sektorze mięsnym obejmują: optymalizację warunków metody HP w celu inaktywacji docelowych mikroorganizmów, nowe systemy pakowania i połączenie z naturalnymi substancjami przeciwdrobnoustrojowymi w celu zwiększenia okresu trwałości, opracowanie nowych produktów mięsnych. Metoda wysokich ciśnień może być zatem stosowana jako skuteczna technologia poprawiająca bezpieczeństwo produktów mięsnych, przy zachowaniu ich wysokiej jakości i przedłużonym okresie trwałości [7, 65].

Ważnym kierunkiem rozwoju wysokociśnieniowego konserwowania jest mięso drobiowe i jego przetwory gotowe do spożycia. Ze względu na swoją specyfikę i niekorzystne efekty sensoryczne, nie zawsze jest możliwe poddanie ich termicznej pasteryzacji, więc konieczne jest znalezienie innej metody zapewnienia bezpieczeństwa sanitarnego takich produktów. Zdarzają się przypadki wycofania dużych partii mięsa ze względu na zanieczyszczenie bakteriami Listeria monocytogenes i innymi patogenami. Powodują one infekcje w $20 \div 30 \%$ przypadków kończące się śmiercią. Poddanie produktów mięsnych działaniu wysokiego ciśnienia już po zapakowaniu wydaje się rozwiązaniem prowadzącym do zmniejszenia liczby zatruć, a w konsekwencji śmierci, spowodowanych tymi bakteriami. Poddanie produktów działaniu wysokiego ciśnienia już przez 3 min powoduje zmniejszenie liczby występujących kolonii bakterii Listeria monocytogenes aż o 5 rzędów wielkości [65].

USFDA zatwierdziła metodę HP jako nietermiczną technologię pasteryzacji, którą można wykorzystywać do zastąpienia tradycyjnej pasteryzacji w przemyśle spożywczym. W Europie metoda ta jest uważane za nową technologię podlegającą rozporządzeniu w sprawie nowej żywności. Proces HP, w którym osiąga się redukcję E. coli O157:H7 o 5 log, powinien być wystarczający dla zapewnienia bezpieczeństwa mikrobiologicznego wytworzonego produktu. Wspólnota Europejska (KE) realizuje między- 
narodowy projekt badawczy dotyczący HP, aby dokonać rzeczywistej oceny potencjału technologii wysokociśnieniowej do komercjalizacji [24, 41].

\section{Podsumowanie}

W ostatnim okresie technologia wysokich ciśnień zyskuje na powszechności na skalę przemysłową jako technologia niskotemperaturowa, przyjazna dla środowiska i pozbawiona odpadów. Wzrost zainteresowania naukowców wykorzystaniem HP w celu inaktywacji patogenów różnych produktów spożywczych, w tym również mięsa i przetworów mięsnych, jest spowodowany głównie niskim zużyciem energii, związanym z zastosowaniem tej metody.

Metoda HP jest alternatywną technologią służącą do zachowania żywności o zmniejszonym zapotrzebowaniu na ciepło i na świecie coraz powszechniej stosowaną do obróbki mięsa i różnych produktów mięsnych. W rezultacie zachowana jest ich wartość odżywcza i wydłużony zostaje okres przydatności do spożycia bez użycia konserwantów lub substancji dodatkowych.

W zależności od zastosowanego poziomu ciśnienia technologia HP wpływa na parametry jakościowe mięsa i przetworów mięsnych, takich jak tekstura i barwa, typowo związane ze świeżym mięsem. Jest to skuteczna metoda umożliwiająca kontrolę drobnoustrojów patogennych.

Wpływ HP na redukcję mikroorganizmów w mięsie i produktach mięsnych oraz skuteczność tej metody są zmienne i zależą od parametrów procesu i samego produktu. Stosowane przemysłowe poziomy ciśnienia mieszczą się w zakresie $400 \div 600 \mathrm{MPa}$. Przy krótkim czasie przetwarzania w temperaturze otoczenia następuje unieczynnienie większości mikroorganizmów chorobotwórczych i powodujących psucie. Jeśli zastosuje się dodatkowe technologie związane z przeszkodami w połączeniu z HP, możliwe jest zwiększenie trwałości i poprawa bezpieczeństwa mięsa.

Opisane zmiany powodowane przez wysokie ciśnienie w składnikach mięsa i przetworów mięsnych, a przede wszystkim w strukturze białek, umożliwiają opracowanie minimalnie przetworzonych produktów mięsnych o korzystnych cechach sensorycznych, reologicznych i teksturalnych. Jednocześnie zmniejszenie aktywności lipolitycznej i proteolitycznej pozwala na zwiększenie trwałości surowców i przetworów mięsnych, a brak zmian w związkach niskocząsteczkowych - na zachowanie ich wartości odżywczej.

\section{Literatura}

[1] Alves A.B., Bragagnolo N., da Silva M.G., Skibsted L.H., Orlien V.: Antioxidant protection of highpressure processed minced chicken meat by industrial tomato products. Food Bioprod. Proc., 2012, 90 (3), 499-505. 
[2] Bajovic B., Bolumar T., Heinz V.: Quality considerations with high pressure processing of fresh and value added meat products. Meat Sci., 2012, 92, 280-289.

[3] Bak K.H., Lindah G., Karlsson A.H., Orlien V.: Effect of high pressure, temperature, and storage on the colour of porcine longissimus dorsi. Meat Sci., 2012, 92, 374-381.

[4] Balny C., Masson P., Heremans K.: High pressure effects on biological macromolecules: From structural changes to alteration of cellular processes. Biochim. Biophys. Acta, 2002, 1595, 3-10.

[5] Buckow R., Sikes A., Tume R.: Effect of high pressure on physicochemical properties of meat. Food Sci. Nutr., 2013, 53, 770-786.

[6] Butz P., Tauscher B.: Emerging technologies: Chemical aspects. Food Res. Int., 2002, 35, 279-284.

[7] Campus M.: High pressure processing of meat products and sea food. Food Eng., 2010, 13, 1-33.

[8] Cegiełka A., Kuczyńska N., Pietrzak D.: Zastąpienie surowca wieprzowo-wołowego w kiełbasach homogenizowanych przez mięso drobiowe oddzielone mechanicznie, uzyskane po separacji wysoko- i niskociśnieniowej. Żywność. Nauka. Technologia. Jakość, 2014, 3 (94), 123-135.

[9] Chan J.T.Y., Omana D.A., Betti M.: Application of high pressure processing to improve the functional properties of pale, soft, and exudative (PSE)-like turkey meat. Innov. Food Sci. Emerg. Technol., 2011, 12 (3), 216-225.

[10] Cheftel J.C., Culioli J.: Effects of high pressure on meat: A review. Meat Sci., 1997, 46 (3), 211-236.

[11] Datta N., Deeth H.C.: High pressure processing. In: Encyclopedia of Dairy Sciences. Eds. H. Roginski, J.W. Fuquay, P.F. Fox. Academic Press, London 2003, pp. 1327-1333.

[12] Dolatowski Z.J., Twarda J., Dudek M.: Zmiany uwodnienia mięsa podczas dojrzewania. Ann. UMCS. Sect. E, 2004, 5 (94), 1595-1606.

[13] Domaradzki P., Litwińczuk Z., Florek M., Litwińczuk A.: Zmiany właściwości fizykochemicznych i sensorycznych mięsa wołowego w zależności od warunków jego dojrzewania. Żywność. Nauka. Technologia. Jakość, 2016, 3 (106), 35-53.

[14] Drużkowski M., Pietrzyk S.: Nowoczesne metody utrwalania żywności. Laboratorium - Przegląd Ogólnopolski, 2006, 32, 8-9.

[15] Dudzińska A., Domagała J., Wszołek M.: Wpływ wysokiego ciśnienia hydrostatycznego na podstawowe składniki mleka. Żywność. Nauka. Technologia. Jakość, 2014, 2 (93), 19-32.

[16] Ferrini G., Comaposada J., Arnau J., Gou P.: Colour modification in a cured meat model dried by Quick-Dry-Slice process and high pressure processed as a function of $\mathrm{NaCl}, \mathrm{KCl}, \mathrm{K}$-lactate and water contents. Innov. Food Sci. Emerg. Technol., 2012, 13, 69-74.

[17] Fonberg-Broczek M., Windyga B., Szczawiński J., Szczawińska M., Pietrzak D., Prestamo G.: High pressure processing for food safety. Acta Biochim. Pol., 2005, 52, 721-724.

[18] Grossi A., Søltoft-Jensen J., Knudsen J.C., Christensen M., Orlien V.: Reduction of salt in pork sausages by the addition of carrot fibre or potato starch and high pressure treatment. Meat Sci., 2012, 92(4), 481-489.

[19] Grossi A., Olsen K., Bolumar T., Rinnan Å., Øgendal L.H., Orlien V.: The effect of high pressure on the functional properties of pork myofibrillar proteins. Food Chem., 2016, 196, 1005-1015.

[20] Guyon C., Meynier A., de Lamballerie M.: Protein and lipid oxidation in meat: A review with emphasis on high-pressure treatments. Trends Food Sci. Technol., 2016, 50, 131-143.

[21] Hać-Szymańczuk E., Mroczek J., Tworzydlak S., Stolpe B.: Wpływ wysokiego ciśnienia na wybrane cechy jakościowe polędwicy sopockiej i surowej polędwicy wędzonej. Żywność. Nauka. Technologia. Jakość, 2005, 4 (45), 42-51.

[22] Hać-Szymańczuk E., Mroczek J.: Zastosowanie techniki wysokich ciśnień w technologii żywności, a szczególnie w przetwórstwie mięsa. Med. Weter., 2006, 62, 637-640.

[23] Hęś M., Korczak J.: Wpływ różnych czynników na szybkość utleniania się lipidów mięsa. Nauka Przyr. Technol,. 2007, 1 (1), 1-11. 
[24] Huang Y., Gan Y., Li F., Yan C., Li H., Feng Q.: Effects of high pressure in combination with thermal treatment on lipid hydrolysis and oxidation in pork. LWT - Food Sci. Technol., 2015, 63, 136143.

[25] Huang H.W., Wu S.J., Lu J. K., Shyu Y.T., Wang C.Y.: Current status and future trends of highpressure processing in food industry. Food Control., 2017, 72 (12), 1-8.

[26] Iwasaki T., Noshiroya K., Saitoh N., Okano K., Yamamoto K.: Studies of the effect of hydrostatic pressure pretreatment on thermal gelation of chicken myofibrils and pork meat patty. Food Chem., 2006, 95 (3), 474-483.

[27] Jung S., Tonello-Samson C.: High hydrostatic pressure food processing: Potential and limitations. In: Alternatives to Conventional Food Processing. Ed. A. Proctor. RSC Publishing, London 2011, pp. 254-305.

[28] Jofré A., Serra X.: Processing of meat products utilizing high pressure. In: High Pressure Processing of Food. Ed. V.M. Balasubramaniam. Springer Science-Business Media, New York 2016, pp. 591623.

[29] Kiełczyński P., Szalewski M., Balcerzak A., Malanowski A., Siegoczyński R.M., Ptasznik S.: Investigation of high pressure phase transitions in DAG (diacylglycerol) oil using the Bleustein-Gulyaev ultrasonic wave method. Food Res. Int., 2012, 49, 60-64.

[30] Kiełczyński P., Szalewski M., Balcerzak A., Wieja K., Rostocki A.J., Siegoczyński R.M., Ptasznik S.: Application of ultrasonic wave celerity measurement for evaluation of physicochemical properties of olive oil at high pressure and various temperatures. LWT-Food Sci. Technol., 2014, 57, 253259.

[31] Kłoczko I., Chudoba T.: Próba zastosowania wysokich ciśnień hydrostatycznych (UHP) do dekontaminacji mięsa zarażonego larwami włośnia (Trichinella spiralis). Bromat. Chem. Toksykol., 2007, XL(2), 195-203.

[32] Knorr D.: Effects of high-hydrostatic-pressure processes on food safety and quality. Food Technol., 1993, 47 (6), 156-161.

[33] Kristensen L., Purslow P.P.: The effect of ageing on the water-holding capacity of pork: Role of cytoskeletal proteins. Meat Sci., 2001, 58, 17-23.

[34] Krzysztofik B.: Oddziaływanie wysokich ciśnień na jakość i trwałość dań gotowych i produktów mięsnych. Przem. Spoż., 2018, (72), 10, 38-42.

[35] Kulisiewicz L.: Konserwacja żywności metodą wysokich ciśnień. Technika Chłodnicza i Klimatyzacyjna, 2003, 12, 448-450.

[36] Liu Y., Hu X., Zhao X., Song H.: Combined effect of high pressure carbon dioxide and mild heat treatment on overall quality parameters of watermelon juice. Innov. Food Sci. Emerg. Technol., 2013, 13, 112-119.

[37] Marcos B., Kerry J.P., Mullen A.M.: High pressure induced changes on sarcoplasmic protein fraction and quality indicators. Meat Sci., 2010, 85, 115-120.

[38] Malinowska-Pańczyk E., Kołodziejska I.: Wpływ połączonego działania wysokiego ciśnienia i innych czynników na mikroorganizmy. Med. Weter., 2007, 63, 515-518.

[39] Malinowska-Pańczyk E., Kołodziejska I.: Możliwości wykorzystania wysokiego ciśnienia w przemyśle mięsnym i rybnym. Med. Weter., 2009, 65, 455-459.

[40] Molenda J.: Selected unconventional methods of food preservation. Med. Weter., 2007, 63 (9), 1016-1020.

[41] Morales P., Calzada J., Ávila M.: Inactivation of Escherichia coli 0157: H7 in ground beef by single-cycle and multiple-cycle high-pressure treatments. J. Food Prot., 2008, 71, 811-815.

[42] Mor-Mur M., Yuste J.: High pressure processing applied to cooked sausage manufacture: Physical properties and sensory analysis. Meat Sci., 2003, 65, 1187-1191. 
[43] Norton T., Da-Wen Sun.: Recent advances in the use of high pressure as an effective processing technique in the food industry. Food Bioproc. Technol., 2008, 1, 2-34.

[44] Northrop D.B.: Effects of high pressure on enzymatic activity. Biochim. Biophys. Acta., 2002, 1595 (1-2), 71-79.

[45] Picouet P.A., Sala X., Garcia-Gil N., Nolis P., Colleo M., Parella T., Arnau J.: High pressure processing of dry-cured ham: Ultrastructural and molecular changes affecting sodium and water dynamics. Innov. Food Sci. Emerg. Technol., 2012, 16, 335-340.

[46] Pietrzak D., Fonberg-Broczek M., Mucka A., Windyga B.: Effect on high pressure treatment on the quality of cooked pork ham prepared with different levels of curing ingredient. High Pressure Res., 2007, 1 (27), 27-31.

[47] Pietrzak D.: Perspektywy stosowania wysokich ciśnień w produkcji żywności wygodnej z mięsa drobiowego. Żywność. Nauka. Technologia. Jakość, 2010, 2 (69), 16-28.

[48] Pietrzak D., Trejda E., Ziarno M.: Wpływ wysokiego ciśnienia na wybrane właściwości oraz trwałość kotlecików z mięsa drobiowego. Żywność. Nauka. Technologia. Jakość, 2011, 1 (74), 68-78.

[49] Popova T., Marinova P., Vasileva V., Gorinov Y., Lidji K.: Oxidative changes in lipids and proteins in beef during storage. Arch. Zoot., 2009, 12 (3), 30-38.

[50] Rodrigues F.R., Rosenthal A., Tiburski J.H., da Gomes Cruz A.: Alternatives to reduce sodium in processed foods and the potential of high pressure technology. Food Sci. Technol. Campinas, 2016, $36(1), 1-8$.

[51] Rodrigues I., Trindade M.A., Caramit F.R., Candoğan K., Pokhrel P.R., Barbosa-Cánovas G.V.: Effect of high pressure processing on physicochemical and microbiological properties of marinated beef with reduced sodium content. Innovative Food Sci. Emerg. Technol., 2016, 38, 328-333.

[52] Rostocki A.J., Ptasznik S., Makała H., Tarakowski R.: Ocena przydatności technologii wysokociśnieniowej do konserwowania mięsa. Studium przypadku. Post. Nauki Technol. Przem. RolnoSpoż., 2018, 73 (1), 5-16.

[53] Romanek J., Opiela J.: Zastosowanie wysokiego ciśnienia hydrostatycznego (HHP) w przemyśle spożywczym, farmaceutycznym oraz medycynie. Wiadomości Zoot., 2015, LIII (4), 34-40.

[54] Sazonova S., Galoburda R., Gramatina I.: Application of high-pressure processing for safety and shelf-life quality of meat - a review. Baltic Conference on Food Science and Technology on „Food for consumer well-being”. Foodbalt 2017, pp. 17-22.

[55] Sikes A.L., Tornberg E., Tume R.K.: A proposed mechanism of tenderising post-rigor beef using high pressure-heat treatment. Meat Sci., 2010, 84, 390-399.

[56] Simonin H., Duranton F., de Lamballerie M.: New insihts into the high-pressure processing of meat and meat products. Comprehensive Rev. Food Sci. Food Saf., 2012, 11, 285-306.

[57] Shahidi F.: Lipid-derived flavours in meat products. In: Meat Processing: Improving Quality. Eds. J. Kerry, J. Kerry, D. Ledward. Woodhead Publishing Ltd, Cambridge 2002, pp. 105-121.

[58] Sonaliben L., Parekh K.D., Aparnathi V.: High pressure processing: A potential technology for processing and preservation of dairy foods. Int. J. Curr. Microbiol. Appl. Sci., 2017, 6 (12), 35263535.

[59] Sun X.D., Holley R.A.: High pressure effects on the texture of meat and meat products. J. Food Sci., 2010, 75, 17-23.

[60] Szczepańska J., Marszałek K., Skąpska S.: Homogenizacja wysokociśnieniowa w przemyśle spożywczym. Przem. Spoż., 2018, 4 (7), 28-30.

[61] Tao Y., Sun D.W., Hogan E., Kelly A.L: High pressure processing of foods: An overview. In: Emerging Technologies for Food Processing. Ed. D.-W. Sun. $2^{\text {nd }}$ ed. Academic Press, London 2014, pp. 3-24. 
[62] Tintchev F., Wackerbarth H., Kuhlmann U., Toepfl S., Knorr D., Hildebrandt P., Heinz V.: Molecular effects of high-pressure processing on food studied by resonance Raman. Annals New York Academy Sci., 2010, 1189, 34-42.

[63] Tonello C.: Case studies on high-pressure processing of foods. In: Nonthermal Processing Technologies for Food. Eds. H.Q. Zhang, G.V. Barbosa-Cánovas, V.M. Balasubramaniam, C.P. Dunne, D.F. Farkas, J.T.C. Yuan. Wiley-Blackwell, Oxford 2010, pp. 36-50.

[64] Wackerbarth H., Kuhlmann U., Tintchev F., Heinz V., Hildebrandt P.: Structural changes of myoglobin in pressure-treated pork meat probed by resonance Raman spectroscopy. Food Chem., 2009, $115,1194-1198$.

[65] Walczyński P.: Nadszedł czas na obróbkę wysokociśnieniową żywności - HPP. Przem. Spoż., 2013, 8 (67), 56-57.

[66] Zhou G.H., Xu X.L., Liu Y.: Preservation technologies for fresh meat - A review. Meat Sci., 2010, $86,119-128$.

\section{HIGH-PRESSURE METHOD APPLIED IN PROCESSING OF MEAT AND MEAT PRODUCTS}

\section{S u m m a ry}

The objective of the research study was to evaluate the potentiality and effectiveness of applying the high pressure method in the processing of meat and meat products and, based on the reference literature data, to point out the development trends for HP technologies.

In the paper, there were presented characteristics of the HP method used in food preservation, principles of applying high pressure to food products and advantages resulting from its use. The shelf life of food products is extended, inter alia, by reducing the count of microorganisms or by decreasing the activity of enzymes. Also a mechanism was explained of destroying microorganisms by high pressure. The potentiality was characterized of the HP method applied in the field of meat and meat products processing. The effect was discussed of high pressure on the changes in the structure of proteins and meat colour, and on the fat oxidation in meat and its products. The options were presented of how to decrease the salt content by using high pressure including its impact on qualitative and sensory features of meat products. The role was described of high pressure in packaged raw meat materials and meat products. The suggestions were listed on how to increase the lethal effect concerning microorganisms by linking the HP method with factors enhancing the synergistic effect of preserving meat and meat products, such as: low $\mathrm{pH}$, carbon dioxide, antimicrobials, vacuum packing or cold storage of products. Also there were pointed out the development trends for the HP method.

Key words: meat and meat products, high-pressure (HP) method, effectiveness of applying HP, trends 